\title{
Virtual Classrooms: Analyzing Student and Instructor Collaborative Experiences
}

\author{
Anita Chadha \\ University of Houston, Downtown \\ ChadhaA@uhd.edu
}

\begin{abstract}
Virtual courses create a self-directed learning environment for students. Given that online environments provide anonymity so that the emphasis is on the content, rather than on the form of the message or the identity of the sender (Herring, 1993) this study assesses students' personal usages in an online collaboration across several states and semesters. In examining the student and instructor perspective, the findings are significant in that, students engage in reflective work employing academic quality discussions across varying institution types from community colleges to public and private universities and that their discussions occur without gender or question type biases. Semester-end surveys confirm that an asynchronous e-learning collaboration enhanced their educational experience and they belonged to a global community of learners. This study adds its significant findings about the growth of online discussions promoting and enhancing the experience of e-learners and collaborative endeavors.
\end{abstract}

Keywords: E-learning, online education. Online collaborations, Asynchronous discussions, online diversity; Global collaborations

Online education has come of age and the acquired taste to deliver these courses becoming the norm. Online courses are the first to fill across various programs and degrees (Bergmann, 2013; Herring, 1993) and to meet the growing demand for more of these types of courses, universities as well as community colleges across the globe are offering increased number of individual courses and degree programs virtually. For universities the benefits abound in higher student enrollment with no physical space requirements. It is estimated that 1.5 million students took part in online education in 1998 (U.S. Department report, 2010) with that figure steadily growing annually.

With this growth online, academic researchers have been evaluating the robustness of online educational offerings through synchronous and asynchronous means (Anderson, 2003; Bergmann, 2013; Farinella, Hobbs, \& Weeks, 2000; Pape, 2010; Graddol \& Swann, 1989; Kiesler et al. 1984 Van Vechten et al, 2013) providing significant positive results about the educational viability of such courses.

\section{Synchronous and Asynchronous Spaces}

The potential advantages and disadvantages of synchronous and asynchronous spaces are evaluated with student needs in mind (Flatley, 2007; Gilmore \& Warren, 2007; Arbaugh, 2000a; Arbaugh, 2000b). Students and instructors can communicate online synchronously using methods such as audio, video, text chat, interactive whiteboard and instant polling. These features enable faculty and students to interact as if they were face to face in a classroom. Participants can talk to each other, view each other through a webcam, use emoticons, and work together in break out rooms. However, asynchronous technologies can be taxing if students feel obligated to be online 
all the time. Students prefer asynchronous technologies such as e-mail, websites, and discussion boards, which give students more independence in when to finish assignments (Dumont, 1996) revisit them, and where they can access them if travelling or deployed. The time and individualized space offerings in an asynchronous format found in distance education, heightens student involvement and participation (Arbaugh 2000a; Webster \& Hackley, 1997; Alavi, Wheeler, \& Valacich, 1995) with students setting an individualized routine when participating in online activities (Allan, 2007). In comparing synchronicity and a synchronicity mediums affecting student achievement, attitudes, and retention, several researchers conclude that asynchrony is more favorable in terms of student outcomes than mediated synchronous or traditional instruction (Bernard, et al., 2004; 2009). Bernard et al. (2004) asserts that knowing the influence of patterns, such as synchronous and asynchronous communication, can guide instructional design when instructors have choice. Researchers add that knowing the advantages and disadvantages of synchronous and asynchronous communication, can guide instructors when designing their courses.

Asynchronous discussions benefits abound. Three of the most cited benefits are, first, interactivity such that students can act as facilitators and provide support, feedback, and guidance during interaction (Khan, 2000). Dirckinck-Holmfield et al. (2004), when their time and space permits. Arbaugh (2000b) highlight the importance of designing virtual communities to enable different patterns and types of interaction, for example, active participation and quieter periods of reflection, or that different user types develop providing engagement in learning (Arbaugh, 2000b; Northrup, 2002). Second is asynchrony, here students use asynchronous technologies such as email, websites, and discussion boards, which require more independence (Dumont, 1996). They can set a personal schedule to participate in online activities (Allan, 2007). The third benefit is that a sense of community develops. Online communities (Allan, 2007) develop when students' membership, influence, integration and fulfillment of needs and shared emotional connection (McMillan \& Chavis, 1986 as described in Arbaugh, 2000a), this happens more so in asynchronous discussions as students define the time and pace of these discussion and can reach out to their peers at any point virtually. In support of this, Ardichvili (2008) asserts that "people tend to actively contribute to online communities when they feel strong commitment to the community ... (p. 544)."

Demands from students taking online asynchronous courses has surged as well. Online discussions provide educational opportunities for students while travelling, deployed, in parallel with a full-time job, or the advantages of taking coursework at their local college or university without living in the same city or having to come to campus thus reducing interruptions to educational experiences. With the additional non-constraints posed by required meeting time and space lifted, students can comply with course requirements in their own personal usage styles. These online discussions encourage critical reflection and dialogue concerning current and theoretical issues in a space and time that is comfortable and familiar to the student. Therefore I seek to understand student perceptions of in the virtual classroom using asynchronous means.

In these virtual asynchronous spaces, users can personalize these spaces irrespective of time constraints and of whom may be participating. For this study, I assess the different kinds of student usage style, creating a composite measure of usage was constructed by combining the number of postings made by each person online, the frequency (or consistency) of their postings and the total number of days they visited the site. Students were scored and placed into one of five categories of users, the back loaders, sporadic users, regular light users, regular and super users. 
The flexibility in connecting students across diverse demographic and cultural environments along with the unknown characteristics such as the gender, race, ethnicity, religion, course level or modes of instruction of the others in the study, provides relatability among these highly diverse groups and in turn challenges viewpoints and develops an awareness of alternative perspectives which can lead to developing a more reflective understanding of collective problems, a deeper appreciation of minority rights, and greater empathy for others (Guttman 2000). Exposure to and experience with diversity can help students develop skills to handle and resolve disagreements arising from conflicting points of view (Zuniga, Vasques-Scalera, Sevig \& Nagda 1997; Gurin, Nagda \& Lopez 2004).

\section{The Online Collaboration}

Research emphasizes the need for collaboration such that knowledge-building occurs in a social peer-exchange based environment among students (Benbunan-Fich, Hiltz, \& Harasim, 2005; Bower, Dalgar no, Kennedy, Lee \& Kinney, 2014; Clark et al., 2015; Goodyear \& Zenios, 2007; Brown \& Duguid, 2000). These peer exchanges in collaborations allow students to collectively construct meaning by integrating various diverse perspectives (Barr \& Tagg, 1995). Collaborations providing students online with the opportunity to "expand their knowledge base together" (Angelino, Williams \& Natvig, 2007, p. 10). Such flexibility that online exchanges provide are essential in creating students' opportunities for learning and academic achievement (Oblinger \& Maruyama, 1996). ${ }^{1}$

This study focuses over several semesters of usage patterns, of an online collaboration requirement that was part of a course grade requirement in an introductory American Politics faceto-face course across three types of universities, a public-four year institution, a private-four year institution, and a community college across three states and time zones. The expectation in this study was that despite differences in educational institution type, students would respond similarly in a space devoid of makers of class, institution, and gender bias or user type in online spaces. Data across gender, race, states and other characteristics showed no significant difference in participation across their posts and responses.

\section{Comparability of Collaboration}

The online collaborative site was purposefully created for this endeavor and only invited students' could join the site ${ }^{2}$. On the collaborative site, a common question was posted on a rotating basis by one instructor that students across all states were required to respond to within the week. All instructors required that their students respond to a minimum of eight of these questions and

\footnotetext{
${ }^{1}$ One instructor initiated this collaboration, followed by other instructors self-initiated there involvement in the collaboration and every instructor had to agree to each institution joining the collaboration. Each instructor was responsible for and performed any work in a timely manner, including obtaining human subject forms filed and approved. Over the next several years, more professors joined the project after hearing about it at the annual APSA Teaching and Learning conferences.

2 Instructors followed IRB and FERPA guidelines on each individual campus. Students were told about the collaborations and its implications for research in class over a period of two weeks, in case a student had not heard it before. The students had to sign a consent form for the collaboration with its implications for research. They were given a choice if they chose not to be a part of the collaboration, an alternative project was assigned to them. Students then had to request permission to join the site, and after the instructor verified their signed consent, they were allowed to join the site. Any student 18yrs or under, had to have parental consent in order to join. Student names are never used in research, but are changed if quoted.
}

Journal of the Scholarship of Teaching and Learning, Vol. 18, No. 3, September 2018. josotl.indiana.edu 
respond to a minimum of eight posts by their peers as well with a 75 word minimum length as a part of their syllabus course grade that ranged from 10-15\%. The courses themselves were identical in content, assignments and structure, each supported by the common collaborative site accessible only by consent of the instructor and relied on semi-scheduled asynchronous participation. The array of in class activities was the same across participating classes, further maintaining the similarities across the collaboration. Instructors rotated responsibility for posing questions weekly across a variety of contemporary and enduring issues in American Politics ${ }^{3}$. None of the professors furthered discussion of the instructor questions in class as well lending to these similarities. Learning goals were outlined in respective syllabi, and included developing a better understanding of other points of view, deepening (students') sense of identity as members of a political community, improving their communication, research, analytical, and critical thinking skills through short writing assignments, including those online (Van Vechten, et. al., 2013). While not a course requirement, several students initiated their own questions furthering a sense of community. Student questions did not duplicate the instructor questions. This several semesterlong analyses gives academics and academic leaders alike a longer term perspective of student usage in online discussions. The students who participated in the program were enrolled in these American Politics courses "virtually" linked by a collaborative project and using asynchronous discussions across different states and time zones. In addition to human subject reports filed on each campus, students were told about the collaboration and its requirement, they were required to sign consent forms if they were above the age of 18, or require parental consent, or ask for an alternative project if they chose not be a part of the collaboration. After consent forms were verified, students could ask for an invitation to join the student members' only collaborative site.

I expect to find that given availability of online spaces and a largely non-existent time line, student usage patterns will be varied based on when they have the time to respond, on their own terms and typically when assignments are due. While most students methodically and consistently participate online, some are at best sporadic in their usage. However, despite varying user types, student interaction in discussing instructor-initiated questions would be reflective with educational acumen irrespective of gender and class boundaries. Online spaces accommodate varying user types, and while we know an increasing amount about online course, how enterprising students make use of online spaces is still to be uncovered.

\section{Determining Student Usage Styles}

Defining usage patterns of undergraduate students across the online collaboration was of interest as these spaces provide a non-existent deadline. Also of interest was if student usage on a site be similar across the differing educational systems. To understand their usage styles, and based on previous work (Van Vechten et al, 2013), a composite measure of usage was constructed by combining the number of postings made by each person, the frequency (or consistency) of their postings (how many they had posted by the $14^{\text {th }}$ week of the semester) and the total number of days they visited the site. Students were scored and placed into one of five categories of users. From those who never used the site, to a rare few who accessed it almost every other day. The "nevers" never posted or posted only once over the term. The "back loaders" or "front loaders" clustered their postings either at the beginning or end of term, posting several times a day, inconsistently. The "sporadic" users, were inconsistent in the frequency of their postings. They

\footnotetext{
${ }^{3}$ As students had to respond to a minimum of 8 posts and responses in a typical 14 week term, they could miss or continue their postings. Posting by students indicate that despite break schedules students continued posting and responding. Journal of the Scholarship of Teaching and Learning, Vol. 18, No. 3, September 2018. josotl.indiana.edu
} 
might post six times in one day and then vanish for weeks. They tended to post about twice a month. These users our "hit and run" posters. The "regular lites" posted throughout the semester fairly regularly, but usually only once a day. They may also have posted consistently and then disappeared for a month. The "regular" users used the site consistently in both frequency and volume; they posted and responded to others' posts either weekly or every other week. The 'super users' posted very frequently and regularly. For instance, in the span of 10 days a super user might post over 20 times.

A composite measure of usage was constructed by combining the number of postings made by each person, the frequency (or consistency) of their postings (how many they had posted by the $14^{\text {th }}$ week of the semester) and the total number of days they visited the site. Students were scored and placed into one of the categories of users. Online spaces should provide equalizing spaces for students on the web, and should be true across educational institutions whether the class was a public, private 4-year or community college educational system. Table 1 lists the mean and standard deviation scores across the four-hundred fifty-eight students members usage across these varied institutions shown in table 1. Mean scores across all institution types and student usage were equivalent. The majority of users that is two-hundred and twenty-eight out of the four hundred and fifty-eight posters were "regular posters", posting on average one to three posts per day across the institutions.

\begin{tabular}{|l|l|l|l|}
\hline \multicolumn{4}{|l|}{$\begin{array}{l}\text { Table 1: Mean and standard deviation scores across } \\
\text { user types and all institutions }\end{array}$} \\
\hline Usage consistency & Mean & N & $\begin{array}{l}\text { Std. } \\
\text { Deviation }\end{array}$ \\
\hline $\begin{array}{l}\text { Back loaded, crammed, } \\
\text { frontloaded, or split }\end{array}$ & 4.8025 & 81 & 1.15564 \\
\hline Sporadic & 4.8000 & 60 & 1.31226 \\
\hline $\begin{array}{l}\text { regular light (many } \\
\text { days, 1 post per day) }\end{array}$ & 4.2154 & 65 & 1.70928 \\
\hline $\begin{array}{l}\text { regular (many days, 1- } \\
\text { 3 posts per day) }\end{array}$ & 4.9518 & 228 & 1.46692 \\
\hline $\begin{array}{l}\text { Super user (many days, } \\
\text { many posts, } \\
\text { consistently) }\end{array}$ & 3.7826 & 23 & 1.80798 \\
\hline Total & 4.7358 & 458 & 1.48886 \\
\hline
\end{tabular}

Eighty-one of the four-hundred fifty-eight students or eighteen percent were "back loaders" or "front loaders." Sixty of the four-hundred fifty-eight students or thirteen percent were "sporadic" posters. Sixty-five of the four-hundred fifty-eight students or fourteen percent were "regular light posters" or posted one post per day. The majority of user types were "regular posters" that is two-hundred and twenty-eight out of the four hundred and fifty-eight posters or fifty percent across the institutions were regular in their postings, posting on average one to three posts per day. Twenty-three of the four-hundred fifty-eight students or less than one percent were super users, these students consistently posting several posts per day. 


\section{The Study Questions and Hypothesis}

Online spaces offer increased access in time, space and pace for students to respond to at their discretion (Graddol \& Swann, 1989; Kiesler et al. 1984). Additionally the ability for students to participate anonymously on the same terms as others with the emphasis being on the content, rather than on the form of the message or the identity of the sender (Herring, 1993) equalizing the opportunity for students to respond and interact. How would these non-constraints online spaces offer differ in students' personal usage type? Would they respond to each other without gender bias? Would they be reflective across the questions asked of them? I analyzed four semesters of the collaboration as different universities participated in different semesters. In measuring usage across participating institutions, I hypothesized that,

H1: Over the course of the semester, student usage type, whether the student was a "back loader/crammer, sporadic, regular lite, regular, or super user”, would be consistent across universities. Students are similar irrespective of institution type (public, private 4-year, or community college educational system). With the meeting space online equalized, students would use the site similarly and score reflective scores irrespective of their user or institution type. Online spaces provide the anonymity, that meeting in person can place, providing for a balanced forum for online courses and based on the quality of question or response posed as well as across institution type.

H2: Over the course of the semester, students used the site according to his or her personal style and achieved reflective scores irrespective of gender differentials. Longstanding patterns of social interaction reflected in the traditional classroom, as seen in men's tendency to dominate discussions and women's tendency to feel marginalized and participate comparatively less (Coates, 1996: Tiene, 2004) would not likely be the case online as the medium subdues or eliminate status cues (Thomas, 2002). Virtual spaces provide the means to equalize spaces providing anonymity and a non-hierarchical space (Graddol \& Swann, 1989; Kiesler et al. 1984) holding true across gender.

H3: Over the course of the semester, students used the site according to his or her personal style and achieved reflective scores irrespective of institution type. Reflectivity was measured by a variable called, "reflective/deliberative" meaning that students had reflected, deliberated, or reconsidered their own views when they responded to questions or when they commented on other students' posts. They puzzled through problems or issues, further questioned others, and challenged others or holding them accountable for their views in a positive way. They deliberated about the question and responded with reflective, thoughtful comments.

Similarly, H4: Over the course of the semester, students used the site according to his or her personal style and achieved reflective scores irrespective of the types of questions asked by instructors. Online deliberative link students across diverse unknowns such as their political views challenging various perspectives (Zuniga, Vasques-Scalera, Sevig \& Nagda 1997; Gurin, Nagda \& Lopez 2004). Online courses also provide anonymity so that the emphasis is on the content, rather than on the form of the message or the identity of the sender (Herring, 1993).

\section{Results}

To measure these hypotheses, content analysis was used first, followed by anovas to test for statistical significance across the semesters and institutions. 


\section{Student Usage Type by Institution}

Student usage types were tested across each institution type through the semesters. Given that online spaces offer the flexibility for users to complete their work, anovas reveal statistical significance $(p<.200)$ across the semester based on user type at the differing institutions in table 2 and support hypothesis 1 . Differing usage types, whether the student was a "crammer, super user" or any other usage style, online students take advantage of the opportunity to respond and interact in a manner that is convenient for them.

\begin{tabular}{|c|c|c|c|c|c|}
\hline $\begin{array}{l}\text { Semester (Hypothesis } \\
\text { support) }\end{array}$ & Df & Mean Square & $\mathrm{F}$ & Sig. & $\begin{array}{l}\text { Partial Eta } \\
\text { Squared }\end{array}$ \\
\hline Corrected Model & 31 & 3.288 & 2.215 & .000 & .191 \\
\hline Intercept & 1 & 200.930 & 135.331 & .000 & .317 \\
\hline Gender (Нyp 2) & 1 & 1.462 & 2.625 & .106 & .000 \\
\hline $\begin{array}{l}\text { Reflectivity across usage } \\
\text { type (Hyp } 1 \text { ) }\end{array}$ & 3 & 2.312 & 1.557 & .200 & .016 \\
\hline $\begin{array}{l}\text { Reflectivity across } \\
\text { institution type (Нyp 3) }\end{array}$ & 4 & 2.906 & 1.957 & .101 & .026 \\
\hline Dq posts (Hyp 4) & 37 & .278 & 2.331 & .000 & .353 \\
\hline $\begin{array}{l}\text { gender * reflectivity } \\
\text { across usage type }\end{array}$ & 3 & 7.543 & 5.080 & .002 & .050 \\
\hline $\begin{array}{l}\text { gender * across } \\
\text { institution type }\end{array}$ & 2 & 5.853 & 3.942 & .020 & .026 \\
\hline Error & 291 & 1.485 & & & \\
\hline
\end{tabular}

Anovas prove that whether the student was a "back loader, crammer, sporadic, regular lite, regular, or super user”, they used the site according to their personal style and scored significant reflective scores irrespective of their user type at these differing institutions. While it is hardly desirous for instructors to have their students cram postings, backload them, be sporadic or irregular in their postings, the student user type depicts that online their use of the site was similar across differing institutions.

\section{Gender Differentials}

Across the semesters, the student responses across gender was tested across each institution type. In support of these perspectives, resulting anovas reveal statistical significance $(p<.106)$ of responses across the semester without gender bias based on user type in table 2 and support hypothesis 2.

Positive confirmation of anovas support prior research confirming that while women are much less likely than men to express political opinions in face-to-face mixed-gender groups (e.g., Karpowitz et al, 2014), in the online format, however, these differences would not be present. Karpowtiz indicates that females' participation online exceeded that of males in the whole-class sample, Thus supporting earlier studies that suggest females prefer opportunities to deliberate in 
writing, rather than face-to-face (Asterhan et al., 2012; Shang-Shan et al., 2012). Data across gender showed no significant difference in participation across their posts and responses.

Reflective across institution type. The educational value of an asynchronous threaded discussion depends upon the thoughtful interaction of the students across different institution types. Online spaces provide an equalizing factor for students to interact and respond reflectively across the questions asked of them. Reflectivity was measured by the variable defined, "reflective/deliberative" meaning that students had reflected, deliberated, or reconsidered their own views when they responded to questions or when they commented on other students' posts. They puzzled through problems or issues, further questioned others, challenged others or held them accountable for their views in a positive way. Anovas reveal statistical significance of the content analysis $(\mathrm{p}<.101)$ across the semester based on the different institution types and reflectivity as shown in table 2 and support hypothesis 3. The student would respond score significant reflective scores irrespective of institution type (public, private 4-year, or community college educational system).

Reflective across discussion questions. Instructors asked questions on a rotating basis throughout the semester. With online spaces devoid of identifying characterizes and relying on the quality of question and response, students do post with reflectivity across discussion questions throughout the semester as revealed by anovas statistical significance $(p<.000)$ testing scores across discussion questions in table 2 and support hypothesis 4 . Running subsequent anova testing of eleven individual instructor-initiated questions in table 3 , show statistical significance $(\mathrm{p}<.087)$ of scores across each question asked. Eleven questions were tested, as the universities started and ended at different times, and so the first two weeks and last week questions were not analyzed.

\begin{tabular}{|c|c|c|c|c|c|}
\hline \multicolumn{6}{|c|}{$\begin{array}{l}\text { Table 3: Significant Anova scores by instructor discussion questions (dqposts) across } \\
\text { classes. }\end{array}$} \\
\hline $\begin{array}{l}\text { Across Semester, support } \\
\text { for hypothesis } 4\end{array}$ & B & Std. Error & $\mathrm{T}$ & Sig. & $\begin{array}{l}\text { Partial Eta } \\
\text { Squared }\end{array}$ \\
\hline Dq posts1 & -3.167 & 1.055 & -3.000 & .003 & .054 \\
\hline Dq posts 2 & -1.000 & 1.146 & -.873 & .384 & .005 \\
\hline Dq posts 3 & -1.000 & .582 & -1.720 & .087 & .018 \\
\hline Dq posts 4 & -1.000 & .646 & -1.547 & .124 & .015 \\
\hline Dq posts 5 & -1.000 & .598 & -1.671 & .097 & .017 \\
\hline Dq posts 6 & -1.000 & .646 & -1.547 & .124 & .015 \\
\hline Dq posts 7 & -2.000 & .992 & -2.016 & .046 & .025 \\
\hline Dq posts 8 & -2.000 & .946 & -2.114 & .036 & .028 \\
\hline Dq posts 9 & -2.000 & .691 & -2.895 & .004 & .050 \\
\hline Dq posts 10 & -1.750 & .623 & -2.810 & .006 & .048 \\
\hline Dq posts 11 & -3.000 & .946 & -3.171 & .002 & .060 \\
\hline
\end{tabular}

In support of the four hypothesis and the resulting significant Anovas supporting the hypotheses throughout this study, post hocs were performed for each and table 4 provides those post hoc significance across the differing institutions, gender and discussion questions. Table 5 provides post hoc significance for scale of reflectivity and campus in table 5. 


\begin{tabular}{|c|c|c|c|c|}
\hline \multicolumn{5}{|c|}{ Table 4: Tukey post hocs by Institution and gender and Lsd post hocs by discussion } \\
\hline \multirow{6}{*}{$\begin{array}{l}\text { (I) Class/professor } \\
\text { 4Year Private }\end{array}$} & \multirow{6}{*}{$\begin{array}{l}\text { (J) Class/professor } \\
\text { community college } \\
\text { community college } \\
\text { 4Year Public } \\
\text { 4Year Public } \\
\text { 4Year Private }\end{array}$} & \begin{tabular}{|l} 
Mean \\
Difference (I- \\
J)
\end{tabular} & Std. Error & Sig. \\
\hline & & $1.0016^{*}$ & .14248 & .000 \\
\hline & & $2.1536^{*}$ & .13840 & .000 \\
\hline & & $1.7976^{*}$ & .15378 & .000 \\
\hline & & $2.4612^{*}$ & .17737 & .000 \\
\hline & & $.9033^{*}$ & .13657 & .000 \\
\hline \multicolumn{5}{|c|}{ Tukey post hocs by gender } \\
\hline \multirow[t]{5}{*}{ By Gender } & community college & -.167 & .083 & .336 \\
\hline & community college & -.268 & .099 & .076 \\
\hline & 4Year Public & -.237 & .120 & .360 \\
\hline & 4Year Public & -.096 & .081 & .843 \\
\hline & 4Year Private & -.192 & 9.112 & .523 \\
\hline \multicolumn{5}{|c|}{$\begin{array}{l}\text { Post hocs across significant anovas of reflectivity scores by scale of reflectivity and } \\
\text { campus. }\end{array}$} \\
\hline \multirow[t]{11}{*}{ DQ 4} & DQ 1 & $1.32034^{*}$ & .25783 & .000 \\
\hline & DQ 2 & $.99275^{*}$ & .34150 & .004 \\
\hline & $\mathrm{DQ} 3$ & .06172 & .20754 & .766 \\
\hline & DQ 4 & .44275 & .23152 & .056 \\
\hline & $\begin{array}{l}\mathrm{DQ} 5 \\
\end{array}$ & $.72003^{*}$ & .28525 & .012 \\
\hline & $\overline{D Q} 6$ & $.80854^{*}$ & .30184 & .008 \\
\hline & DQ 7 & $.88164^{*}$ & .30835 & .004 \\
\hline & DQ 8 & $.96644^{*}$ & .30184 & .001 \\
\hline & DQ 9 & $1.22003^{*}$ & .28525 & .000 \\
\hline & DQ 10 & -.05035 & .17712 & .776 \\
\hline & DQ 11 & .33650 & .24917 & .178 \\
\hline
\end{tabular}

Journal of the Scholarship of Teaching and Learning, Vol. 18, No. 3, September 2018. josotl.indiana.edu 


\begin{tabular}{|c|c|c|c|c|c|}
\hline $\begin{array}{l}\text { Table 5: } \\
\text { Post hocs ac } \\
\text { campus. }\end{array}$ & ross significant Anovas of & f reflectivity scores by sc & of reflect & ity anc & \\
\hline & (I) Scale of reflectiveness & (J) Scale of reflectiveness & \begin{tabular}{|l} 
Mean \\
Differen \\
ce (I-J)
\end{tabular} & $\begin{array}{l}\text { Std. } \\
\text { Error }\end{array}$ & Sig. \\
\hline Tukey HSD & $\begin{array}{l}\text { Not reflective; } \\
\text { summarizing without }\end{array}$ & $\begin{array}{l}\text { Somewhat reflective; } \\
\text { some substance }\end{array}$ & & .084 & .000 \\
\hline & adding to discussion & $\begin{array}{l}\text { Reflective; adds } \\
\text { substantively to } \\
\text { discussion }\end{array}$ & $-.59^{*}$ & .124 & .000 \\
\hline & & $\begin{array}{l}\text { Very reflective; adds } \\
\text { substantially to } \\
\text { discussion }\end{array}$ & $-1.19^{*}$ & .317 & .001 \\
\hline LSD & 4Year Public & 4Year Private & -.6346 & .38453 & .101 \\
\hline & & Community College & $.7717^{*}$ & .22634 & .001 \\
\hline & 4Year Private & 4Year Public & .6346 & .38453 & .101 \\
\hline & & $\overline{\text { Community College }}$ & $1.4063^{*}$ & .37410 & .000 \\
\hline & $\overline{\text { Community College }}$ & 4Year Public & $-.7717^{*}$ & .22634 & .001 \\
\hline & & $\overline{\text { 4Year Private }}$ & $-1.4063^{*}$ & .37410 & .000 \\
\hline
\end{tabular}

Across differing institutions, online spaces provide a meeting place where students respond and perform across usage styles, gender and institution differentials while their academic performances remain robust. Virtually students perform in engaged and reflective discussions online, these spaces providing for students' engagement with the course materials, heightening their online discussions, and deepening their thinking about course-related concepts, theoretical principles, and research findings. A mixed methods approach to test for these relationships first by content analyses of students' discussions and then by anovas and post hoc testing significance provide empirical findings that students respond with depth of learning across all questions asked throughout the semester.

\section{Concluding thoughts and continued research needs}

While focusing on the study of student usage patterns in a virtual format is interesting for its own sake, it is also interesting in light of understanding student styles when interacting with peers. Aside from the user perspective, the similar student usage patterns across states, time zones and instructional type demonstrates an understanding of meaningful academic exchanges comparing online educational experiences across four-year public, four-year private institutions and a community colleges. Significant results from this study find support for asynchronous collaborations where students discuss instructor-initiated discussion boards and in responses to peers across educational institution types, gender, and with academic vigor. The powerful potential of online spaces is revealed.

Conversations online never really end providing a variety of student usage styles to develop and perform. Thus, the open-ended nature of the online class discussions helped some students reflect, deliberate and re-think over the semester. Clearly, this is a great advantage over real-time 
face-to-face courses where, once a discussion ends, it is moved to the next discussion. In the online space, class discussions do not need an end, illustrating the kind of distributed learning across time and place that is possible online-a real advantage over more static forms of learning and instruction. Online classes can establish a learning climate which is conducive to developing a community of inquiry, "a cohesive and interactive community of learners whose purpose is to critically analyze, construct, and confirm worthwhile knowledge” (Garrison \& Vaughan, 2008, p. 9) as time and space to reflect prevail. Four-year public, four-year private institutions and a community college were a part of this collaboration. It provides an opportunity for this researcher to examine differences in reflectivity across the institution type, as all other content and requirements were identical across this online collaboration. Post survey results across institution type instructor and student initiated discussion questions, articles or links posed with a question and the fact that the visited the site more than ten times other than writing their required posts and subsequently re-visiting the form are well strongly supported as outlined in table 6

\section{Table 6: End of Semester Survey by Institution type}

\section{"Strongly agreed" with the following about the use of the following features in your Collaborative American Politics class?}

\section{Answer Options (reported as percent)}

Instructors' Discussion Questions of the Week

Not helpful or mostly unhelpful for my understanding of

American Politics.

Neither helpful nor unhelpful for my understanding of American

Politics.

Mostly helpful or very helpful for my understanding of

American Politics.

Student-Generated Discussion Questions

Not helpful or mostly unhelpful for my understanding of

American Politics.

Neither helpful nor unhelpful for my understanding of American

Politics.

Mostly helpful or very helpful for my understanding of

American Politics.

Articles or Links posted to the site

Not helpful or mostly unhelpful for my understanding of

American Politics.

Neither helpful nor unhelpful for my understanding of American

Politics.

Mostly helpful or very helpful for my understanding of

American Politics.

\begin{tabular}{ll}
$\begin{array}{l}\text { Four- } \\
\text { year } \\
\text { Public } \\
\text { Univ }\end{array}$ & $\begin{array}{l}\text { Community } \\
\text { College }\end{array}$ \\
\hline 2 & 1 \\
\hline 1 & 4 \\
\hline 15 & 12 \\
\hline 18 & 17 \\
\hline 2 & 1 \\
\hline 5 & 5 \\
\hline 11 & 11 \\
\hline 18 & 17 \\
\hline 2 & 2 \\
\hline 16 & 6 \\
\hline
\end{tabular}

Journal of the Scholarship of Teaching and Learning, Vol. 18, No. 3, September 2018. josotl.indiana.edu 


\begin{tabular}{l|l|l}
\hline & 18 & 17 \\
\hline Did you re-visit the forum other than writing a post? & 11 & 11 \\
Did you visit the site more than ten times other than posts? & 14 & 3
\end{tabular}

Online deliberations have the potential to reduce and even eliminate barriers that prevent female or across institutional type from feeling comfortable participating in face-to-face deliberations. As findings reveal that females tend to prefer anonymous conditions when deliberating online suggests a promising avenue of investigation toward the goal of creating neutral spaces for students to deliberate controversial issues. Online spaces do provide opportunities for students to express their ideas and benefit by exposure to a broader range of perspectives. In these online deliberations, students are able to practice in a controlled, teacher-supported environment. While face-to-face deliberations will not, nor should they, disappear from the classroom, incorporating anonymous online forums may provide opportunities for less participatory students to contribute and develop valuable democratic skills. Research dictates that the likelihood for a post to include reflective comments occurs if it is to be evaluated ( $\mathrm{Vu}, 2015)$. By constructing deliberative experiences in education our students, instructors and universities greatly benefit.

Increasing research in this area concludes that higher online usage is associated with higher academic performance based on peer learner participation (Fejes, Johansson, \& Abrandt Dahlgren, 2005). And that online course delivery opens up new areas of accessibility at the undergraduate and graduate study level (Powel et al. 2014), across states, time zones and globally achieving a higher level of quality in course delivery and, ultimately, produces a better model for cost effectiveness than competing course design and delivery models. Yet another study reveals that using information technologies make students not just to consume technology but also lead them to produce it. Spending time online means that several make some contributions to their knowledge about information technologies (Mujgan, 2015).

In examining the nature of classroom discussions in face-to-face as well as twenty-three online courses a study reveals that students demonstrate their learning of the course contents online occurs when they explain the course readings in their own words and given time to reflect. Others demonstrated their learning by posting either applied examples or personal anecdotes, some of which were not clearly related to the course contents. Undoubtedly, students often feel more comfortable with challenging text materials when they can rely upon personal examples as the student 'owns' those experiences providing meaning to abstract theories and complicated research findings (Bonk et al., 2003). The future of online education is definitely bright. Online educational spaces provide an equitable forum across comparable topics at every level of education and institutional type.

As online learning has integrated mainstream, transcending geographical boundaries is another aspect of openness already opening up opportunities across the nation. The results proven here are in favor of an emerging model of heightened for online courses to be offered on a local, regional, national or international scale, a challenge for future research and collaborations. 


\section{References}

Alavi, M., Wheeler, B. C., \& Valacich, J. S. (1995). Using IT to re-engineer business education: An exploratory investigation of collaborative tele learning. MIS Quarterly, 19(3), 293-312.

Allan, B. (2007). Time to Learn? E-learners' experiences of time in virtual learning communities. Management Learning, 38(5), 557-573. doi:10.1177/1350507607083207

Anderson, T. (2003). Modes of interaction in distance education: Recent developments and research questions. In M.G. Moore \& W. G. Anderson (Ed.), Handbook of Distance Education. Mahwah, New Jersey: Lawrence Erlbaum Associates Inc.

Angelino, L. M., Williams, F. K., \& Natvig, D. (2007). Strategies to engage online students and reduce attrition rates. The Journal of Educators Online, 4(2), 1-14.

Arbaugh, J. B. (2000a). Virtual classroom versus physical classroom: An exploratory study of class discussion patterns and student learning in an asynchronous online MBA course. Journal of Management Education, 24(2), 213-233. doi:10.1177/105256290002400206

Arbaugh, J. B. (2000b). Virtual classroom characteristics and student satisfaction with online MBA courses. Journal of Management Education, 24(1), 32-54.

doi:10.1177/105256290002400104

Ardichvili, A. (2008). Learning and knowledge sharing in virtual communities of practice: Motivators, barriers, and enablers. Advances in Developing Human Resources, 10(4), 541-554. doi:10.1177/1523422308319536

Ardichvili, A. (2008). Learning and knowledge sharing in virtual communities of practice: Motivators, barriers, and enablers. Advances in Developing Human Resources, 10(4), 541-554. doi:10.1177/1523422308319536

Asterhan, C., Schwarz, B., \& Gil, J. (2012). Small-group, computer-mediated argumentation in middle-school classrooms: The effects of gender and different types of online teacher guidance. British Journal of Educational Psychology, 82 (3), 375-397. doi:10.1111/j.20448279.2011.02030.

Barr, R. B., \& Tagg, J. (1995). From teaching to learning: A new paradigm for undergraduate education, Change, 27(6), 13-25.

Benbunan-Fich, R., Hiltz, S. R., \& Harasim, L. (2005). The online interaction learning model: An integrated theoretical framework for learning networks. In S. R. Hiltz and R. Goldman, Learning together online. Mhwah, NJ: Lawrence Erlbaum Associates

Bernard, R.M., Abrami, P.C., Lou, Y., Borokhovski, E., Wade, A., Wozney, L., Wallet, P .A. Fiset, M., Huang, B. (2004). How does distance education compare with classroom instruction? A meta-analysis of the empirical literature. Review of Educational Research, 74(3), 379-439. 
Bergmann, Jon (2013). The Flipped Classroom: A Student's Perspective. http://researchnetwork.pearson.com/learning-science-technology/the-flipped-classroom-astudents-perspective

Bonk, C., \& Zhang, K. (2006). Introducing the R2D2 model: Online learning for the diverse learners of this world. Distance Education, 27(2), pp. 249-264. Doi: 10.1080/01587910600789670

Bonk, C. J., Wisher, R. A., \& Lee, J. (2003). Moderating learner-centered e-learning: Problems and solutions, benefits and implications. In T. S. Roberts (Ed.). Online collaborative learning: Theory and practice. Hershey, PA: Idea Group.

Bower, M., Dalgarno, B., Kennedy. G., Lee, M. J. W. \& Kinney, J. (2014). Blended Synchronous Learning: A Handbook for Educators. Office for Learning and Teaching. Sydney, AU: Department of Education. https://blendsync.org/handbook

Brown, J. S., \& Duguid, P. (2000). The Social Life of Information. Boston: Harvard Business School Press.

Benbunan-Fich, R., Hiltz, S. R., \& Harasim, L. (2005). The online interaction learning model: An integrated theoretical framework for learning networks. In S. R. Hiltz and R. Goldman, Learning together online. Mhwah, NJ: Lawrence Erlbaum Associates.

Busbin, W. B. (2013). Can deliberation occur? Student decision-making about Controversial political issues in online, face-to-face, and blended formats. (Unpublished doctoral dissertation). Auburn University, Auburn, AL.

Clark, Christopher H.; Bordwell, Daniel T.; and Avery, Patricia G. (2015) "Gender and Public Issues Deliberations in Named and Anonymous Online Environments," Journal of Public Deliberation: Vol. 11: Iss. 2, Article 2.

Coates, J. (1986). Women, men, and language. New York: Longman. Dirckinck-Holmfield, L., Sorensen, E. K., Ryberg, T. and Buus, L. (2004) 'A Theoretical Framework for Designing Online Master Communities of Practice’, in S. Banks et al. (Eds) Networked Learning, pp. 267-73. Lancaster: University of Lancaster.

Dumont, R. A. (1996). Teaching and learning in cyberspace. IEEE Transactions on Professional Communication, 39(4), 192-204.

Farinella, J. A., Hobbs, B. K., \& Weeks, H. S. (2000). Distance delivery: The faculty perspective. Financial Practice and Education, 10, 184-194.

Flatley, M. E. (2007). Teaching the virtual presentation. Business Communication Quarterly, 70(3), 301-305. doi:10.1177/1080569907305305 
Fejes, A., Johansson, K., \& Abrandt Dahlgren, M. (2005). Learning to play the seminar game: Students' Initial encounters with a basic working form in higher education. Teaching in Higher Education, (10)1, 29-41.

Garrison, D. R. (2006). Online collaboration principles. Journal of Asynchronous Learning Networks, 10(1), 25-34.

Garrison, D. R., \& Vaughan, N. (2008). Blended learning in higher education. San Francisco: Jossey-Bass Publishers.

Gilmore, S., \& Warren, S. (2007). Themed article: Emotion online: experiences of teaching in a virtual learning environment. Human Relations, 60(4), 581-608. doi:10.1177/0018726707078351

Goodyear, P. \& Zenios, M. (2008) Discussion, collaborative knowledge work and epistemic fluency. British Journal of Educational Studies. 55(4), 351-368.

Graddol, D., \& J. Swann. (1989). Gender Voices. Oxford: Basil Blackwell.

Gurin, P., Nagda, B. A., \& Lopez, G. (2004). The benefits of diversity in education for democratic citizenship. Journal of Social Issues , 60 (1), 17-34.

Guttman, A. (2000). Why should schools care about civic education? In L. McDonnell, P. M. Timpane, \& R. Bejamin (Eds.), Rediscovering the democratic purposes of education. Lawrence, KS: University Press of Kansas.

Herring, Susan. (1993). Gender and Democracy in Computer-Mediated Communication. Electronic Journal of Communication: http://www.cios.org/EJCPUBLIC/003/2/00328.HTML

Harlina Halizah Siraj, Abdus Salam, Nurul Ashiqin bt Hasan, Tan Hiang Jin, Raihanah Binti Roslan, Muhammad Nazam Bin Othman(2015). Internet Usage and Academic Performance: A Study in a Malaysian Public University. International Medical Journal Vol. 22, No. 2, pp. 83 86.

Karpowitz, C., \& Mendelberg, T. (2014). The silent sex: Gender, deliberation, and institutions. Princeton, NJ: Princeton University Press.

Khan, B. H. (2000). Discussion of resources and attributes of the web for the creation of meaningful learning environments. CyberPyschology \& Behavior, 3(1), 17-23.

Kiesler, S., J. Seigel, \& T. W. McGuire. (1984). Social psychological aspects of computer mediated communication. American Psychologist, 39:1123-1134.

Larson, B. E. (2003). Comparing face-to-face discussion and electronic discussion: A case study from high school social studies. Theory \& Research in Social Education, 31, 347-365.

doi:10.1080/00933104.2003.10473229 
Mujgan and Geyik (2015). An Empirical Research on General Internet Usage Patterns of Undergraduate Students. Procedia - Social and Behavioral Sciences Volume 195, 3 July 2015, Pages 895-904.

National Center for Education Statistics. (1999). Distance education at postsecondary institutions, 1997-1998 (NCES Report 2000-013).Washington, DC: Author.

Northrup, P. T. (2002). Online learners' preferences for interaction. The Quarterly Review of Distance Education, 3(2), 219-226.

Oblinger, D. G., \& Maruyama, M. K. (1996). Distributed learning (CAUSE Professional Paper Series No. 14). Boulder, CO: CAUSE

Pape, L. (2010). Blended Teaching \& Learning. School Administrator, 67 (4), 16-21.

Powell, M., \& Jacques (2014). The Graduate Virtual Classroom Webinar: A Collaborative and Constructivist Online Teaching Strategy. Journal of Online Learning and Teaching

Shang-Shan, C., Zhi-Feng Liu, E., Nian-Shing, C., Ru-Chu, S., \& Chiung-Sui, C. (2012). Gender differences in college students' behaviors in an online question-answer discussion activity. Asia-Pacific Education Researcher, 21(2), 244-256.

Thomas, M. J. W. (2002). "Learning with Incoherent Structures: The Space of Online Discussion Forums.” Journal of Computer Assisted Learning, 18(3): 351-366.

Tiene, Drew. (2004). "Online Discussions: A Survey of Advantages and Disadvantages Compared to Face-to-Face Discussions.” Journal of Educational Multimedia and Hypermedia, 9: 371.

U.S. Department of Education report (2010). Evaluation of evidence-based practices in online learning: A meta-analysis and review of online learning studies. Retrieved from http://www2.ed.gov/rschstat/eval/tech/evidence-based-practices/finalreport.pdf

Van Vechten, Renée et. al. (2013). How Students Talk to Each Other: An Academic Social Networking Project. Chapter 11 in Alison Rios Millett McCartney and Elizabeth Bennion, Eds. Teaching Civic Engagement: From Student to Active Citizen. Washington, D.C.: The American Political Science Association.

Vu Minh Chieu, Karl W. Kosko, Patricio G. Herbst (2015). An Analysis of Evaluative Comments in Teachers' Online Discussions of Representations of Practice. Journal of Teacher Education, vol. 66 no. $135-50$

Webster, J., \& Hackley, P. (1997). Teaching effectiveness in technology-mediated distance learning. Academy of Management Journal, 40(6), 1282-1309. 
Zuniga, X., Vasques-Scalera, C., Sevig, T. D., \& Nagda, B. A. (1997). Exploring and bridging race/ethnic differences: Developing intergroup diaglogue competencies in a co-learning environment. Paper presented at the American Educational Research Association Meeting. Chicago, IL. 